\title{
Production of Cellulolytic Enzymes by Aspergillus flavus Using Solid State Fermentation Based on Sugarcane Bagasse
}

\author{
Side ney Becker Onofre ${ }^{1,2, *}$, Géss ica C. Silva ${ }^{1}$, Shaiana P. Mattie llo ${ }^{1}$, Deizi Groth ${ }^{1}$, Ivair Malagi ${ }^{1}$ \\ ${ }^{1}$ Department of Biological Sciences and Pharmacy, FAED - Faculty of Educational of Dois Vizinhos - União de Ensino do Sudoeste do \\ Paraná - UNISEP - Av. Presidente Kennedy, 2601 - Bairro Nossa Senhora Aparecida - Dois Vizinhos - Paraná - Brazil \\ ${ }^{2}$ M icrobiology Laboratory, Department of Biological Sciences and Health, Paran aense Univ ersity - UNIPAR, Unit of Francisco Beltrão, Av. \\ Julio Assis Cavalheiro, 2000, Bairro Centro, Francisco Beltrão, Paraná, Brazil
}

\begin{abstract}
Cellulases are enzy mes of great industrial interest, which are used in the food, pharmaceuticals, cosmetics, detergents and textile industries. Applications include the bleaching of pulp in the paper industry, the production of dissolved pulp, waste water treatment and recycling of waste paper. Studies have been carried out regarding the ability of microorganis ms to produce enzymes, using available and affordable substrates. The aim of this study was to evaluate the ability of the endophytic fungus Aspergillus flavus, strain (D2-FB) to produce cellu lase. The studies were carried out using a substrate of sugarcane bagasse supplemented with $1 \%$ cellobiose and carboxy methylcellulose. The material was kept in an oven at $27^{\circ} \mathrm{C}$ for 69 days and the enzymes were measured every 7 days. To quantify the enzy mes, the DNS method was adopted. The results showed that the highest production occurred at 32 days, with a production of $33.15 \pm 7.96 \mathrm{U} / \mathrm{g}$ of substrate. After this period, the en zy me production decreased gradually up to $3.06 \pm 0.53 \mathrm{U} / \mathrm{g}$. Based on these results, it can be concluded that the endophytic fungus A. flavus, strain (D2-FB), is a producer of cellu lases.
\end{abstract}

Keywords Enzymes, Bioprocesses, Biotechnology, Fermentation

\section{Introduction}

Enzymes are biological catalysts, consisting of protein molecules produced by living cells. These biocatalysts have a high catalytic activity and specific selectivity for the substrate[1].

Cellulases are enzymes that are capable of breaking cellulose's glycosidic bonds, resulting in the release of oligosaccharides, cellobiose and glucose[2]. These hydrolytic enzymes are used in the food, pharmaceuticals, cosmetics, detergents and textile industries. Their main applications include the bleaching of pulp in the paper industry, the production of dissolved pulp, waste water treatment and recycling of paper residues. Enzyme technology is currently one of the most promising new technology fields for the synthesis of valuable compounds.

Industrial processes that employ en zy mes in biotransform ation processes have a lower environmental impact and concomitantly lower consumption of energy, since they are biodegradable and highly specific, which reduces undesirable effects $[3,4]$.

* Corresponding author:

becker@unisep.edu.br (Sideney Becker Ono fre)

Published online at http://journal.sapub.org/ajb

Copyright (C2013 Scientific \& Academic Publishing. All Rights Reserved
A wide variety of cellulase-producing microorganis ms are present in nature, and they are capable of degrading natural cellu lose. Cotton and filter paper, among others, are used as inducing substrates for the production of exo-glycosidases and for measuring the activity of the total cellulolytic complex[5]. Among the microorganisms, fungi are noteworthy for producing enzymes of industrial interest. Fungi are uni or multicellular eu karyotic organis ms, which are heterotrophic, chemoorganotrophic, aerobic or microaerophilic; some have cell walls composed of chitin and cellulose[6].

The genus Aspergillus sp. is the most common filamentous fungus, and is one of the most thoroughly studied. The species of this genus are distributed worldwide and are present on the surface, in air and water, both in plant organisms and in animals, and are associated with the deterioration of plant materials and food. Many species of Aspergillus are used to obtain enzymes, in chemical biosynthesis and transformation of compounds [7].

Agroindustrial wastes and low-cost cellulosic biomass can be used to produce cellulases, which not only greatly reduces the cost of production of these enzymes but also may result in a yield similar to that obtained with other carbon sources as well as contributing to the environment. Several agro-industrial residues can be used as a substrate, such as orange bagasse, wheat and rice bran, soybean, apple pulp, 
coffee pulp, sugar cane bagasse, passion fruit peel, pineapple bagas se and cashew apple pulp[2].

Bagasse from sugarcane has been used as a substrate for growing large numbers of microorganisms, including bacteria, yeasts and filamentous fungi. However, fungi are the most commonly used, due to the amount of enzy mes and proteic enrichment that they produce. The bagasse has been used as a substrate for the production of cellulases and xy lanases by various Aspergillus species, including A. niger and $A$. phoenicis $[8,9]$.

The objective of this study was to evaluate the ability of the endophytic fungus Aspergillus flavus, strain (D2-FB), isolated from Baccharis dracunculifolia D.C (Asteraceae) to produce cellulases.

\section{Materials and Methods}

\subsection{Studied Microorganis m}

This study used the endophytic fungus Aspergillus flavus, strain (D2-FB), is olated from Baccharis dracunculifolia D.C. (Asteraceae), isolated in the period 2008 to 2009 and kept in the fungi collection of the Microbiology Laboratory of the Universidade Paranaense - Unipar - Unidade Universitária de Francisco Beltrão - PR.

\subsection{Determination of the Cellulolytic Activity}

For the determination of cellulolytic activity, the study used a basic support of sugarcane bagasse that was successively rinsed in water for complete removal of sugars. The rinsed pulp was dried in an oven with air circulation at $65{ }^{\circ} \mathrm{C}$ for 24 hours, and was then packed in a polyethylene bag and stored in a dry environment.

\subsection{Fermentation in Erlenmeyer Flasks}

$1 \%$ cellobiose and $1 \%$ carboxymethylcellulose were added to the sugarcane bagasse substrate to induce the production of cellulases and as the medium's in itial carbon sources. This mixture was inoculated with a suspension of $5 \mathrm{~g}$ of the fungus, previously grown on a rice medium. It was then homogenized in an Erlenmeyer flask and incubated at $28^{\circ} \mathrm{C}$ for 69 days.

\subsection{Analysis of the Fermented Substrate}

Aliquots of five grams of the medium were collected every 7 days and mixed with $50 \mathrm{ml}$ of distilled water in the presence of 7.0 buffer. This suspension was stirred continuously for 30 minutes. It was then filtered to remove solids to yield a clear extract used for $\mathrm{pH}$ measurement. The extract was centrifuged at $3000 \mathrm{rpm}$ for 15 minutes and the supernatant was considered an enzyme source to determine reducing sugar via the indirect spectrophotometric method. The indirect spectrophotometric method was used to determine enzyme activity based on the release of glucose molecules by the action of the cellulolytic enzy mes complex.

\section{4. $\mathrm{pH}$}

$\mathrm{pH}$ was measured on a suspension obtained after homogenization of $5 \mathrm{~g}$ of ferment in $50 \mathrm{ml}$ of distilled water, which was continuously stirred for 30 minutes.

\subsection{Dosage of Reducing Sug ars}

Reducing sugars were determined by the reaction with 3,5-din itrosalicy lic "DNS"[10]. In an alkaline mediu m and at elevated temperature, the 3,5-dinitrosalicylic turns into 3-amino-5-nitrosalicylic. It develops a yellowish coffee color that absorbs at $540 \mathrm{~nm}$. One unit of cellulases was defined as the quantity of released enzy me capable of acting on the substrate and releasing one $\mu$ mol of reducing sugar (expressed as glucose) per minute under the test conditions [11].

\section{Results and Discussion}

The data obtained from the fermentation process using a substrate of sugarcane bagasse supplemented with $1 \%$ carboxy methylcellu lose and cellobiose, inoculated with the endophytic fungus Aspergillus flavus, isolated from Baccharis dracunculifolia D. C. (Asteraceae), are shown Fig. 1.

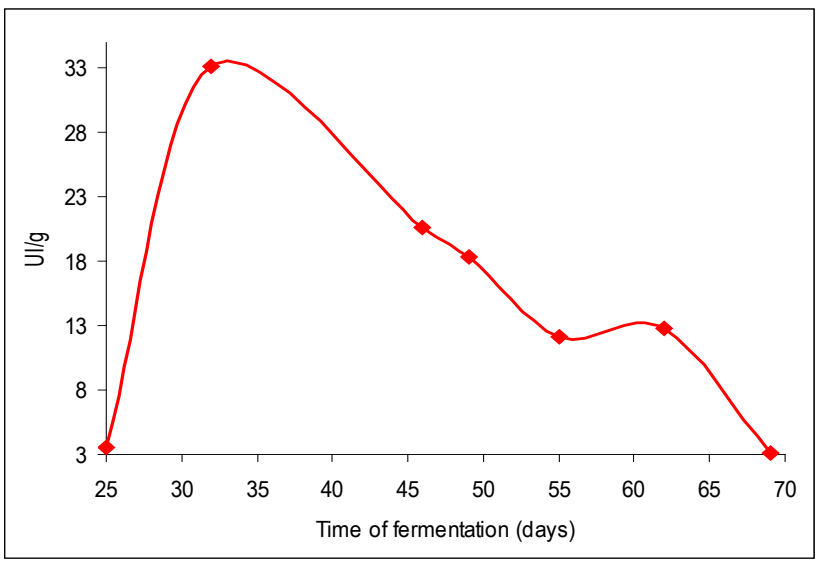

Figure 1. Behavior of the endophytic fungus Aspergillus flavus, strain (D2-FB), in the production of cellulolytic complex in solid fermentation at a temperature of $28^{\circ} \mathrm{C}$ and $\mathrm{pH}$ of 6.54

The data analysis showed that the cellulase production, measured over 69 days, was $3.50 \pm 0.40 ; 33.15 \pm 7.96$; $20.63 \pm 6.54 ; 18.35 \pm 9.22 ; 12.11 \pm 5.46 ; 12.85 \pm 4.87$ en zy me units for each gram of fermented substrate for the times of 25 , $32,46,49,55,62$ and 69 days of fermentation, respectively.

Thus, it can be seen that the period of greatest expression of the cellu lase enzy me occurred at 32 days of fermentation; after this period the expression rate gradually decreased, stabilizing at 55 and 62 days, and decreasing again at 69 days.

After 32 days of fermentation there was a decrease in the volume of the produced cellulase enzyme, which indicates genetic repression of this enzyme. The phenomenon of gene 
suppression is due to the formation of a cascade of signals initiated within the cell by the presence of the signal molecule (glucose). This activates the repressor molecule, which binds in the promoter region of the cellulase genes, blocking the transcription and expression of these genes[12-16].

According to Soccol[11], $\mathrm{pH}$ monitoring is an important variable in the optimal conditions of enzy matic activity, because the fungus has a limited ability to grow under extreme conditions of acid ity and a lka linity. In this study, the $\mathrm{pH}$ of the medium remained stable (between 6.2 and 7.7). The temperature is also a very important variable, because it interferes with the optimal conditions for activity of an enzy me[17]; in th is study the initial te mperature was $28^{\circ} \mathrm{C}$.

Pandey[18] who studied the enzyme $\alpha$-amylase at temperatures between 28 and $37^{\circ} \mathrm{C}$, achieved excellent results. In the same year, the same author obtained highest yields of $\alpha$-amylase with Aspergillus niger at a temperature that ranged from $28-30^{\circ} \mathrm{C}$, which coincides with the fermentation process conditions used in this study.

Various substrates are used in order to obtain large amounts of cellulolytic enzy mes by microorganisms $[19,20]$. This study used a substrate of sugarcane bagasse supplemented with $1 \%$ carboxymethylcellulose and cellobiose, which favored the production of cellulases. Likewise,[21] found that using a mixed culture of Aspergillus fumigatus and Aspergillus ellipticus, developed in sugarcane bagasse pre-treated with $2 \%$ calciu m hydro xide solution, favored the production of cellu lase, after 8 days of fermentation.

In a study by Menezes et al.[22], the cellu lolytic activity of fungal strains, such as Aspergillus niger, grown in sugarcane bagasse was higher than those grown only in carboxymethylcellulose and filter paper. The authors suggested that these strains produce the exoglucanase fraction, since the bagasse is an in natura cellulose and had not received any chemical treatment, which would require the action of the pre-hydrolytic fraction of exoglucanase before being hydrolyzed by the other endoglucanase and $\beta$-glucosidase fractions.

The results of this study were higher than those obtained by Zúñiga[23], which evaluated the production of cellulases by Aspergillus niger grown in solid state fermentation on supplemented sugarcane bagasse. They obtained $0.59 \mathrm{U} / \mathrm{g}$ substrate using the same cultivation conditions. This difference can be explained by the fact that they used different species and the medium had different chemical and physical factors, which would cause the fungi to behave differently.

Milagres et al.[24], studied submerged fermentation in a med iu m based on hemicellulose hydrolysate from sugarcane bagasse using Thermoascus aurantiacus and obtained enzyme activities of 4.2 and $3.3 \mathrm{U} / \mathrm{g}$ substrate for endoglucanase and exoglucanase, respectively. These values are also lower than the maximum activity obtained in this study.
Umikalson[25], who worked with a strain of Chaetomium globosum in delignified palm fiber, obtained similar results to those obtained in our study. Their activities of total cellulase, enduglucanase and $\beta$-glucosidase were $1.4,30.8$ and $9.8 \mathrm{U} / \mathrm{g}$ of substrate, respectively. The similarity of these results reinforces the idea that even though filamentous fungi may belong to a different genus, they have the same behavior when cultivated in specific media and conditions.

\section{Conclusions}

It can be concluded that the endophytic fungus Aspergillus flavus, strain (D2-FB) is able to produce enzymes of the cellu lolytic complex. Therefore, its use in processes to obtain enzymes and produce energy sources such as glucose and cellobiose is extremely important. Sugarcane bagasse, used as substrate, was able to induce the expression of genes responsible for production of cellu lases by the endophytic fungus Aspergillus flavus, strain (D2-FB), given that significant amounts of enzymes were obtained. The fermentation time that led to the highest production of the enzy me was 32 days, with a yield of $33.15 \pm 7.96$ enzyme units/gram of substrate, at $\mathrm{pH} 6.82$ and a temperature of $28^{\circ} \mathrm{C}$.

\section{ACKNOWLEDGEMENTS}

We would like to thank IBAMA - Brazilian Institute for the Environment, for the license for collection of biological material and the União de Ensino do Sudoeste do Paraná, for financing this project.

\section{Conflict of Interest}

The authors declare no conflict of interest.

\section{REFERENCES}

[1] S. Said and R. Pietro, "Generalidades sobre aplicação industrial de enzimas". In: Enzimas como agentes biotecnoló gicos. Ribeirão Preto: Legis Summa. p.1-7, 2004.

[2] R.T.P. Correia. "Estudo do cultivo semi sólido em resíduos de abacaxi por Saccharomyces cereviseae e Rizhopus oligosporus". Tese Programa de Pós Graduação em Engenharia Química, Universidade Federal do Rio Grande do Norte. Natal, RN. 2004.

[3] E.P.E. Bom, "Enzimas industriais: política e gestão". In: Seminário Brasileiro de Tecnologia Enzimática, 2002, Brasília. Anais... Brasília, DF. 2002, 230p.

[4] S. Mitidiere, "Produção de protease para formulação de detergentes biodegradáveis”. In: Seminário Brasileiro de Biotecnologia Enzimática, 2002, Brasília. Resumos...Brasília, DF, 2002. 
[5] L.M. Robson and G.H. Chambliss, "Cellulases of bacterial origin". Enzyme and Microbial Technology. Vol.11, pp.626-644, 1989.

[6] M.F.S. Teixeira, "Micologia médica: manual de laboratório. Manaus": UFAM, 111 p, 2004.

[7] C.A.R. Rosa, S.G. Campos and F.A. Baroni, "Práticas de micologia veterinária". UFRRJ. Instituto de Veterinária. Departamento de Micologia e Imunologia Veterinária. Micologia Veterinária. Prática 8. Seropédica. 128p, 2002.

[8] A. Pandey, "Biotechnological potential of agro-industrial residues". I: Sugarcane bagasse. Bioresource Technology. Vol.74, pp.69-80, 2000.

[9] C. Sánchez, "Lignocellulosic residues: biodegradation and bioconversion by fungi". Biotechnology Advances. Vol.27, pp.185-194, 2004.

[10] G.L. Miller, Use of dinitrosalicylic acid reagent for determination of reducing sugar. Analytical Chemistry. Vol.31, pp.426-428, 1959.

[11] C.R. Soccol, "Physiologie et Métabolisme de Rhizopus en Culture Solide et Submergée en Relation Avec la Dégradation d'Amidon et la Production d'Acide L(+) Lactique". Thèse de Doctorat. Mention Génie enzymatique, Bioconversion et Microbiologie, Université de Tecnologie de Campiègne. Compiègne-France, 218 p, 1992.

[12] H. Ronne, "Glucose repression in fungi". Trends Genet. Vol.23, pp.76-79, 2005.

[13] J. Strauss, "Crel, the carbon catabolite repressor protein from Trichoderma reesei“. FEBS Lett. Vol.376, pp.103-107, 2008.

[14] G.F.G. Ruijter and J. Visser, "Carbon repression in Aspergilli”. FEMS Microbiol. Lett. Vol.151, pp.103-114, 2006.

[15] M. Ilmén, "Regulation of cellulose gene expression in the filamentous fungus Trichoderma reesei". Appl. Environ. Microbiol., Vol.63, pp.1298-1306, 1997.
[16] S. Ozcan and M. Johnston, "Function and regulation of yeast hexose transporters". Microbiol. Mol. Biol. Rev. Vol.63, pp.554-569, 1999.

[17] A.L. Lehninger, "Princípios de Bioquímica". 8 a ed. São Paulo: Savier Editora de livros Médicos Ltda, 2003, 725p.

[18] A. Pandey, "Enzyme Technology". 1 ed. New Delhi: Asiatech Publishers, Inc, 2005.

[19] D.M. Silva and A.J.P. Dillon, "Produção de celulases em fermentação semisólida por uma linhagem de Trichoderma sp". In: Reunião anual de genética de microrganismos, 15., 1988. Anais... Piracicaba: FEALQ, p 54, 2004.

[20] A. Dillon, 2004. Celulases. In: Said, S.; Pietro, R. C. L. Enzimas como agentes biotecnoló gicos. Ribeirão Preto: Legis Summa. Vol.22, pp.243-270, 2004.

[21] A. Gupta and D. Madamwar, "Solid state fermentation of lignocellulosic waste for cellulase and betaglucosidase production by cocultivation of Aspergillus ellipticus and Aspergillus fumigatus." Biotechnology Process. Vol.13, pp.166-169, 1997.

[22] T.J.B. Menezes, P.R. De Lamo and T. Arakaki, "Produção do complexo celulolítico $\mathrm{C} 1, \mathrm{Cx}$ por microrganismos". Coletânea do ITAL. Vol.21, pp.213-219, 1976.

[23] U.F.R. Zúñiga, "Influência do Meio Nutricional na Produção de Celulases em Fermentação Semi Sólida do Bagaço de Cana de açúcar por Aspergillus niger". XVII Simpósio Nacional de Bioprocessos, Natal - RN, 2009.

[24] A.M.F. Milagres, L. Borges and C.L. Aguiar, "Degomagem de rami para fins têxteis utilizando extratos enzimáticos". Anais do SHEB. Vol.4, pp.261-269, 2004.

[25] M.S. Umikalson, "Production of cellulase by a wsild strain of Chaetomium globosum using delignified oil palm empty-fruit-bunch fibre as substrate". Applied Microbiology and Biotechnology. Vol.47, pp.590-595, 1997. 